\title{
From the Russian Revolution to the Cuban Revolution
}

Steve Cushion

\begin{abstract}
The Cuban Communist Party was the most significant working-class response to the Russian Revolution in the Caribbean. Recent research shows that organised workers played a decisive role in the outcome of the Cuban Revolution, but if the working class role has been hidden from history, the revolutionary activity of Afro-Cuban workers has been doubly obscured. There is a direct connection that links the Russian Revolution to the Cuban Revolution.
\end{abstract}

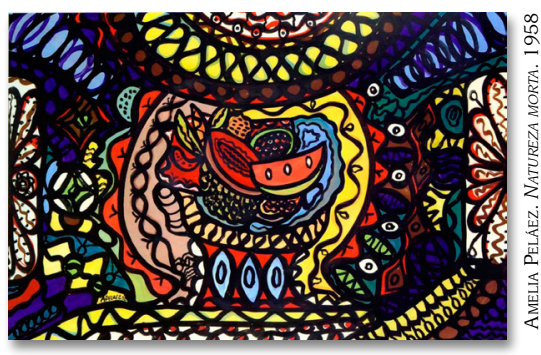

Keywords: Workers. Afro-Cuban. Communism. Revolution.

\section{Da Revolução Russa à Cubana}

\section{$\overline{\text { Steve Cushion }}$}

Retired university lecturer. Secretary of Caribbean Labour Solidarity and Branch Secretary of the University and Colleges Union, London Retired Members.

E-mail: s.cushion23@gmail.com.
Resumo: $O$ Partido Comunista Cubano foi a mais expressiva resposta à Revolução Russa no Caribe. Pesquisas recentes mostram que os trabalhadores organizados tiveram um papel decisivo no resultado da Revolução Cubana, mas, se o papel da classe operária foi omitido na história, a atividade revolucionária dos trabalhadores afro-cubanos foi duplamente obscurecida. Há uma conexão direta que liga a Revolução Russa à Revolução Cubana.

Palavras-chave: Trabalhadores. Afrocubanos. Comunismo. Revolução.
RECEBIDO 23.02.2017 APROVADO 11.04 .2017 


\section{INTRODUCTION}

Just over 40 years separate the Russian and Cuban Revolutions, but they seem a world apart. The first, at least in its early stages, was a classic workers' revolution. The Cuban Revolution, however, has presented a much more complicated picture, with the standard historiography stressing the role of a guerrilla vanguard and seeing little or no role for the proletariat as seen in classic Marxist theory. However, recent research has shown a much greater involvement by organised labour, so perhaps there is a more significant "red thread" linking the two revolutions (CUSHION, 2016a). The Partido Comunista de Cuba (PCC, Cuban Communist Party), formed in 1925, was the most significant response to the Russian Revolution in the Caribbean and it also provided an organisational home for many Afro-Cuban working class militants. But if the working-class role has been hidden from history, the revolutionary activity of AfroCuban workers has been doubly obscured. This article will trace the history of the Afro-Cuban relationship with communism from the party's foundation through to the rebel triumph: that is, from the Russian Revolution to the Cuban Revolution.

\section{BACKGROUND}

By the middle of the Nineteenth Century, Cuba and Puerto Rico were all that remained of the once vast Spanish empire in the Americas. The rest of the empire had gained its independence from Spain in a series of bitter wars that started in 1810 and finally ground to a halt in the middle of the 1820s, although Spain only renounced sovereignty over all of continental America in 1836 (CHASTEEN, 2006). The Cuban economy was based on plantation slavery and fear of slave revolt outweighed any desire for independence on the part of the slave-owning creole oligarchy, while many loyalists fled from the newly independent republics and a large proportion of the defeated Spanish army were redeployed to the island. This fear of their enslaved labour force by the local elite and the large military presence placed great obstacles in the path of cuban independence, but the loyalism of their owners gave the enslaved afro-cuban population every reason to believe that their 
best chance for emancipation lay with supporting the struggle for national independence (PINO-SANTOS, 1964).

In order to understand the place of Afro-Cuban politics in the wider Cuban context, it is first necessary to look at the form that resistance to slavery took in Cuba. The demographics of the island were such that Afro-Cubans in general and slaves in particular were in a minority, as there was a substantial free peasant farming population of Spanish heritage. There were also large numbers of people of mixed African and European heritage, or mulatos, and free people of colour. There had been several anti-slavery conspiracies and localised rebellions in the 18th and early 19th century, but by the 1850s, most Afro-Cubans pinned their hopes for freedom and equality on fighting alongside the nationalists of European descent.

By the late 1860s, the east of the island was in crisis; many planters were heavily in debt and resented their lack of political rights. So when Carlos Manuel de Céspedes freed his slaves in 1868, armed them and called for an uprising, he struck a widespread chord. In the resulting Ten Years War, thousands of slaves fled from their plantations and joined the rebel army. The uprising was defeated by the Spanish forces but it took 10 years and eastern Cuba was devastated. The final peace treaty between the government and the leaders of the rebel forces granted freedom to all those slaves who had fought in both the rebel and the royalist armies. The peace only lasted a year and the war broke out again, with the rebel forces led by an Afro-Cuban rebel general, Antonio Maceo and his brother José. But Spanish forces defeated Maceo's troops in 1880. Under cover of the fighting, many slaves just fled to the remote mountains between Santiago and Guantanamo where they lived by subsistence farming. Their descendants would provide a valuable base for the liberated area set up by Raul Castro and Juan Almeida almost eighty years later, in 1958. The freeing of those slaves who had rebelled, while those who had not remained enslaved, so seriously undermined the institution that the colonial administration abolished slavery in 1886 (FERRER, 1999).

The other long term importance of the Ten Years War was the greatly increased patriotic sentiment, while the experience of black 
and white fighting alongside one another became a central part of the nationalist ideology. Cuban rebel patriots began to define their nation in terms of anti-racism in contrast with the European colonisation of Africa and the growth of the Jim Crow laws that enforced racial segregation in the Southern United States.. There was a considerable gap between rhetoric and practice, but it did give Cuban civil rights activists a useful ideological tool with which to attack official racism. It also set a pattern whereby the much more Afro-Cuban east of the island came to see itself as Oriente rebelde (or Rebellious East).

The war for independence broke out again in 1895 in a context of an economic crisis. The Maceo brothers were again important leaders and Afro-Cubans provided much of the rank and file of the rebel army. The revolution gave them a gun and thereby a stake in society. The USA invaded in 1898 and, while initially welcomed by the rebels, quickly proved by their racist contempt for all Cubans that this was just another imperial conquest (FONER, 1972). They officially left in 1902, leaving a nominally independent Cuba, but in reality the new country was completely dominated by US capital and subject to military threats any time Cuban radicals contested the US puppet government.(PÉREZ, 1990; IBARRA CUESTA, 1998; FONER, 1972).

There were two attempts at independent political organisation by Afro-Cubans, the Partido Independiente de Color (PIC, Independent Party of Coloured People) in 1908 and the United Negro Improvement Association (UNIA) in the late 20s. The PIC, which was centred in the East, was set up by Afro-Cuban veterans of the War of Independence who felt the nationalist ideology of racial equality was hollow. They staged a revolt in 1912 that was in reality a peaceful but armed demonstration. This was brutally repressed with as many as 6,000, both active participants and civilian bystanders, being massacred by the army with the help of US Marines from the Guantanamo base (CASTRO FERNÁNDEZ, 2008).

The United Negro Improvement Association (UNIA), which was led by Marcus Garvey, a Jamaican-born black nationalist who created a Back to Africa movement in the United States, had considerable presence in Cuba during 1920s, again mainly in the east. But 
the membership was largely confined to immigrant sugar workers from Jamaica, Trinidad and Dominica as well as among the Haitian immigrant workforce, although records have been found of at least one Spanish-speaking chapter in Santiago de Cuba (RIVERO, 2005). Given the racism that so many immigrants suffered, the UNIA became largely a self-help association for workers from other Caribbean islands. The big difference between the two organisations was that the Partido Independiente de Color represented black Cubans who were discriminated against and who were claiming their rights as Cuban nationals. The UNIA was a largely immigrant organisation that had no such national rights to claim and whose public face spoke of the homeland in Africa (RIVERO, 2005).

In any case, in the racist backlash that derailed the 1933 Cuban revolution, most of the British West Indian workers were deported to Jamaica. Many Jamaican immigrants also joined the Cuban Communist Party (PCC), which had been founded in 1925, and indeed there was considerable overlap with the UNIA despite the apparent political differences. While most British West Indian workers were temporary residents, by the early 1930s some Jamaicans had become Cuban citizens. At the port of Nuevitas, for example, the leaders of the dock workers were mostly Jamaican and Haitian and most of these immigrants were also Cuban citizens (FUENTE, 1997, p. 44). Hugh Clifford Buchanan, one of the first Marxists in Jamaica, worked in Cuba in the 1920s, where he had been a member of the UNIA and had close contacts with the PCC (HART, 2002).

\section{PARTIDO COMUNISTA DE CUBA}

In the period after the First World War, most Cubans felt that independence was merely formal, that the establishment of the Republic had vastly increased the already-present penetration of the economy by US capital and that corruption had become endemic. Cuban workers reacted to a deterioration in their social conditions by beginning to organise on a class basis. Between 1917 and 1920, more than 220 partial and general strikes occurred, affecting a wide range of industries across the whole the island. Out of this 
wave of industrial action, the second National Workers' Congress emerged in 1920, becoming the first united trade union organisation to cover the whole country. This formed part of a radical nationalist opposition milieu that developed from a new generation challenging the political domination of the veterans of the War of Independence of 1895-98. In the second decade of the twentieth century, a speculative boom known as the Dance of the Millions, largely financed by loans from US banks, had collapsed and most of the Cuban industry had passed into American ownership when the banks foreclosed (POLLITT, 2004). Sugar was always the backbone of the Cuban economy and the sugar price crisis of 1920-21 caused great political instability and a large number of strikes in 1923. From this situation, new political alliances started to emerge.

The Partido Comunista de Cuba (PCC, Communist Party of Cuba) grew out of three strands of this new opposition: radical students around Julio Antonio Mella; artists and intellectuals such as the writer Rubén Martínez Villena; and trade unionists like Alfredo López, who played a key role in the foundation of the first national trade union confederation, the Confederación Nacional Obrera de Cuba (CNOC, National Workers' Confederation of Cuba). These strands initially coalesced in the Universidad Popular José Martí (José Martí People's University), which acted as a forum for political education and debate, as well as a social space where workers, students, intellectuals and artists could come together with the intention of creating a "cultural counter-hegemony" (HATZKY, 2008, p. 121). For this generation, the Russian Revolution, of which little specific information was available, held huge symbolic importance as it legitimated the concept of revolution as the road to modernity (WHITNEY, 2001).

When a communist party was established in 1925, the question of "race" was not discussed at the founding congress and none of the 13 delegates were of African descent. The main focus was on anti-imperialist activity, aiming towards an alliance of radical nationalists committed to the struggle for social justice which took the organisational form of the Liga Anti-Imperialista de Cuba (LAIC, Anti-Imperialist League of Cuba). LAIC was founded by Julio Antonio Mella, also the leading light in the newly formed PCC 
(KERSFFELD, 2009, p. 17-25). The beginnings of the PCC were far from easy as they coincided with a hardening of the repression under the dictatorship of President Gerardo Machado.

Faced with a series of strikes in 1925, the government started to use the army and police to eliminate opposition. The first victim was the railway workers' leader, Enrique Varona, who had recently organised a railway strike in solidarity with striking sugar workers; he was shot by the police in full public view (ZANETTI; GARCÍA, 1987, p. 302). This repression quickly fell on the newly-formed communist party when, two weeks after its founding conference, 200 communists were arrested and the party general secretary, José Miguel Pérez, an immigrant from the Canaries, was deported. When José Antonio Mella was arrested, he began a hunger strike. While this tactic was eventually successful and he was released in January 1926, it was in defiance of a party instruction not to continue and he was expelled for indiscipline from the party that he had been instrumental in founding. Danger of assassination by the regime forced Mella to flee into exile in Mexico, where he was warmly welcomed by his Mexican comrades and Cuba's loss became Mexico's gain as he contributed greatly to the development of the growth of communism in his new home. This self-inflicted wound was strongly criticised both within the Komintern and within the broader milieu of the movement in opposition to the dictatorship. It seriously undermined the fledgling party's influence.

The Communist International (Komintern) arose from the Russian Revolution as an international party of world revolution and the national communist parties were, in theory, sections of the International. The Komintern, in a move aimed at setting up regional structures, established a hierarchy whereby weaker parties were assigned to the tutelage of "elder brother" parties. Given the sensitivity of the historical relations between the USA and Cuba, one wonders at the wisdom of assigning the Cuban party to the sphere of influence of the Communist Party of the USA (CPUSA). Nevertheless, the Caribbean Bureau of the Komintern was based in New York under the watchful eye of the North American party. Nevertheless, it would have the effect of orienting the PCC to work amongst Afro-Cubans. 


\section{KOMINTERN AND THE “NEGRO QUESTION” IN THE USA}

The early US communists had not taken the question of racism particularly seriously. Technically-correct positions on workers unity and on the decisive effects of racial divisions had not been translated into practical activity. Nevertheless, the CPUSA had recruited some important Afro-American and West Indian members, mainly in New York. The black members of the US delegation to the 6th Congress of the Communist International in 1928 were strongly critical of the neglect of work amongst AfroAmericans and they gained a sympathetic hearing in Moscow. The upheaval in the international communist movement resulting from the adoption, at that same 6th Congress, of the so-called Third Period thesis, which condemned social democracy as socialfascism, nevertheless resulted in a change of leadership in the CPUSA and the start of serious agitational work amongst AfroAmericans in the US South (ZUMOFF, 2015, p. 330-352). In turn this led to a similar change in orientation in the Cuban party, which began equally serious agitation amongst Afro-Cubans, particularly in Oriente province in the east of the Island.

As part of this reorientation, in 1929 the CPUSA raised the Right of Self-Determination in areas of the South with a black majority population, the so-called Black Belt". The PCC then adopted a similar position in 1932, even using a direct translation: Franja Negra. It has been hotly debated as to whether the subsequent successes in recruiting workers of African heritage were because of this policy, or despite it (ADI, 2013, p. 81-85; ZUMOFF, 2015, p. 341-355). The demand for self-determination was controversial inside the PCC at the time and not widely publicised and was quietly dropped in 1935. Given the long tradition of Afro-Cubans fighting for civil rights and equality within the Cuban nation, as well as the importance of inter-racial solidarity in many important workers struggles, it is unlikely that this demand would have attracted many recruits.

However, the debate on the Franja Negra did have the effect of initiating serious practical discussion inside the PCC about how to extend their influence and membership in the black community. The second party congress in February 1934 passed a self-critical 
resolution deploring the "ineffectual work among the Negro masses" while setting up and prioritising a Comité Pro Derechos del Negro (Committee for Negro Rights) with equality and anti-discrimination now firmly in the programme (ROJAS BLAQUIER, 2005, p. 206-236). But it was the party's determined involvement in the sugar strikes of 1933 that would really allow them to recruit large numbers of Afro-Cuban workers, including some important black workers' leaders.

\section{REVOLUTION}

In 1930, the US Congress greatly increased tariffs on imported sugar which exacerbated the already serious impact on the Cuban sugar industry of restricted markets and shrinking prices outside the USA. This, combined with the depressing effects of the Wall Street Crash of 1929, led to a general strike in that same year (POLLITT, 2004). On advice from the Komintern Caribbean Bureau, the Cuban Communist Party (PCC) and the Cuban National Workers Confederation (CNOC) made a priority of organising amongst workers in the sugar industry, leading in December 1932 to the founding of the Sindicato Nacional Obrero de la Industria Azucarera (SNOIA, National Workers' Union of the Sugar Industry) and the growth of the PCC from 350 members in 1930 to 6,000 in 1934.

In August 1933 the Machado regime faced a massive general strike which had started amongst Havana bus drivers and spread like wildfire. Desperate to save something from the situation, the dictator met the $\mathrm{CNOC}$ strike committee and agreed to meet all their demands. On the basis of an analysis that "the present general strike is a step towards the revolution, but is not yet the revolution itself" the CNOC, on advice from the PCC leadership and not without some bitter wrangling, called for a return to work once the economic demands had been achieved (ROJAS BLAQUIER, 2005, p. 180-181). The overwhelming majority of the striking workers, indeed most party members, took scant notice of the return to work order and the general strike continued until an army mutiny led by Sergeant Fulgencio Batista removed Machado and installed 
a university professor, Ramón Grau San Martín, as president, and the radical nationalist Antonio Guiteras as Minister of the Interior.

So why did the PCC leadership make what became known as the August Mistake? There were obviously personal, subjective failings, but there is a logic flowing from the sectarianism of the Third Period that goes as follows: "A revolution is only genuine if it is led by the Communist Party. The Communist Party is not leading this general strike. Therefore this is not a real revolution". However, once they realised their mistake, and perhaps determined to salvage their tarnished reputation, the PCC threw themselves enthusiastically into the sugar workers' strikes which followed. Stressing "class against class" and denying the importance of race and nation made practical sense to the PCC in the multi-ethnic sugar industry.

\section{SUGAR SOVIETS}

The overthrow of the Machado dictatorship was accompanied by a wave of industrial action in the sugar industry. By 1932, wages in the industry were the lowest since the end of slavery almost half a century earlier. As the army and local authorities collapsed, this led to a weakening of the repressive apparatus of the state and created a space in which the sugar workers could take action. In many places the strike advanced into an occupation, with strike committees, supply committees and militias. This led Blas Roca, a mulatto shoemaker from Manzanillo and future general secretary of the PCC, to issue a call on behalf of the party to set up soviets. Many of the strike committees in the occupied plantations adopted the title "soviet", although this was mainly giving a name to what they were already doing (CARR, 1996).

Following an attack at the beginning of October 1933 on the Hotel Nacional, where much of the Army General Staff was holed up, Batista secured control of the army and began his rise to dominate Cuban politics (KAPCIA, 2002, p. 287-289). The army then moved to crush the sugar workers' insurgency. But it was not just the repression that brought it to an end; divisions between native Cubans and immigrant workers from the British West Indies 
and Haiti also played a role. The nationalist government of Ramón Grau introduced a Law for the Nationalisation of Labour, which provided that all firms must employ at least fifty percent native Cuban labour, and began to deport British West Indian and Haitian immigrants. In theory directed against the privileged position of Spanish workers in the economy, this law enabled politicians to channel Cuban workers' demands into merely seeking employment at the expense of the foreign-born rather than genuine socialist measures. Many Afro-Cuban workers supported this measure and the divisions weakened the sugar insurgency in some key areas. The PCC resolutely opposed the "50\% law" from a principled anti-racist position and while this alienated many workers, it did attract a significant minority of class-conscious black Cubans (ROJAS BLAQUIER, 2006, p. 206-207).

Following the defeat of the 1933 sugar workers' revolt, Batista consolidated his power and in January 1934 removed Grau from office and replaced him with a series of puppet governments. Despite increased repression, workers' struggles, albeit increasingly of a defensive nature, continued until March 1935, when another general strike broke out. This time, the government declared martial law and used the most extreme violence to force a return to work after 72 hours. The last remains of the revolutionary wave that started in 1933 were broken, the CNOC was banned and the communist party was forced underground (PCC, 1985, p. 332-340; ALEXANDER, 2002, p. 61-68).

\section{POPULAR FRONT}

The defeat of the Cuban workers' movement was not the only such defeat in the early 1930s. The rise to power of the Nazis in Germany over the destruction of one of the strongest working class movements in the world caused a rethink in the international communist movement. The 7th Komintern Congress in July/ August 1935 prioritised anti-fascist work and proposed the creation of Popular Fronts: alliances of all "progressive" forces against fascism. For the Cuban party, reeling from the defeat of the 1935 general strike, this policy was knocking at an open door and was 
enthusiastically endorsed by the PCC Central Committee in October 1935 (ROJAS BLAQUIER, 2006, p. 8-16).

The "progressive force" with which they were to form an alliance was unlikely in the extreme. Fulgencio Batista was never accepted by the Cuban upper classes, in part because of his mixed heritage. He realised that he had a narrow social base and that, once he had defeated organised labour he might in turn become surplus to upper-class requirements. His arrangement with the communist party was in essence that he would, in return for their support, legalise the party and allow them to build a trade union confederation, as well as enacting socially progressive legislation and allowing elections for an assembly to discuss a new constitution. The resulting 1940 constitution was the most progressive in Latin America. It included paid holidays, 48 hours pay for 44 hours work, reinstatement of workers victimised after the 1935 general stri$\mathrm{ke}$, increased protection from dismissal and pension funds in the major industries (CANTÓN NAVARRO, 2013, p. 52). The communists, now renamed the Partido Socialista Popular (PSP, People's Socialist Party), became the leading lights in a new national trade union confederation, the Confederación de Trabajadores de Cuba (CTC, Cuban Confederation of Workers), whose general secretary was the Afro-Cuban communist Lázaro Peña.

During the Second World War, in order to gain popular support for its war against Nazi Germany and Fascist Italy, the US government tolerated reformist regimes in Latin America that introduced popular welfare measures and granted workers the right to organise. As long as the USSR was an ally of the United States, the PSP remained an acceptable part of the governing coalition. However, the situation changed radically after the defeat of the Axis Powers when the USSR quickly became the new "totalitarian" enemy of the self-designated "Free West". Taking advantage of the changed situation, employers and governments looked for ways to reverse the wartime reforms and to restore profitability in the difficult post-war economic circumstances. The anti-Communist hysteria, which the US government generated by in order to justify the change of policy towards the Soviet Union, was also used by ruling elites everywhere to purge trade unions of left-wing militants of all 
political persuasions and to domesticate the remaining leaders, in order to restore a business-friendly atmosphere and increase profit margins at the expense of workers' wages and conditions.

In the particular circumstances of Cuba in the late 1940s, this involved a mixture of government intervention and gangster violence. Following the 1944 elections, Batista was replaced by governments of the Partido Revolucionario Cubano - Auténtico (PRC-A, Cuban Revolutionary Party - Authentic), a liberal nationalist party led by the same Ramón Grau San Martín who had briefly been president following the 1933 revolution. Despite these revolutionary roots, by the mid-1940s the Auténticos, as the PRC-A was commonly known, were committed to the economic and political status quo, were subservient to the sugar oligarchy and fully accepted Cuba's subordinate relationship with the USA. However, the party faced one of the strongest trade union movements in Latin America. Under pressure from the US ambassador, the Grau government encouraged its supporters in the union federation, known as the Comisión Obrera Nacional Auténtica (CONA, National Workers' Commission of the PRC-A) led by Eusebio Mujal, to take over the CTC. The murder of two prominent Afro-Cuban communist trade union leaders serves to illustrate the onslaught (CUSHION, 2016b).

\section{JESÚS MENÉNDEZ}

Jesús Menéndez joined the Cuban Communist Party in 1931 and a year later he became a founder member of the National Workers' Union of the Sugar Industry (SNOIA). He contributed to the 1932-3 wave of militancy as one of the leaders of the union local at Central Constancia, the sugar plantation where he worked. Between 1935 and 1939 Jesús Menéndez was active in the sugar industry during the harvest period while working in the tobacco industry during the "dead season", building his reputation as a militant workers' leader in Las Villas province through his involvement in a strike at Central Constancia in 1936. The dispute was successful in achieving a twenty percent wage increase, but Menéndez was dismissed by his employers after the return to work. In 1937, the 
regional labour movement was strong enough to call the Congreso Provincial Obrero de Las Villas (Provincial Workers' Congress of Las Villas) and the following year Jesús Menéndez was elected its secretary-general. In 1939 Menéndez was elected to the founding executive committee of the CTC. That same year he helped form the Federación Nacional de los Obreros Azucareros (FNOA, National Federation of Sugar Workers) and was elected deputy general secretary, becoming general secretary the following year. Under his leadership, the FNOA merged with the unions of the engineers and administrators to form the Federación Nacional de los Trabajadores Azucareros (FNTA, National Federation of Sugar Industry Workers).

Jesús Menéndez was elected on a communist ticket as a congressional representative in 1942. Following the entry of the USA and the USSR into the Second World War, President Batista, who had been elected in 1940, appointed two communist party members to his cabinet; and the FNTA, under the leadership of Jesús Menéndez, made effective use of the communist party's connections with government, as well as of the increased need of the United States for sugar imports, in order to improve the economic standing of sugar workers. It is estimated that the union negotiated wage increases for its members worth over 300 million dollars between 1941 and 1947 (SIMS,1993), although this has to be set against a very high rate of inflation for basic necessities during the war. The FNTA also won paid holidays and the setting up of a retirement fund.

After the Allied victory in 1945, the US government began negotiations for a new trade agreement with the intention of reducing the cost of imported sugar. The FNTA sought the inclusion of organized labour in the official negotiating team, but the new President, Grau San Martín, initially refused and Jesús Menéndez went privately to Washington in an attempt to win US trade union support for the Cuban position. In the aftermath of the failed negotiations, the Cuban government withheld part of the 1946 sugar harvest and President Truman sent his Secretary of Agriculture to negotiate directly in Havana. This time, Jesús Menéndez was included in the official negotiating team and succeeded in inserting a Guarantee Clause in the agreement which linked the price paid 
for sugar to inflation in goods imported from the USA. This resulted in a diferencial (differential) of 36 million dollars, from which the FNTA forced the government to distribute 25 million pesos amongst the sugar workers as a bonus.

The onset of the Cold War gave the government the opportunity to rid itself of the Cuban communists. Once Minister of Labour Carlos Prío had managed to split the Confederation of Cuban Workers (CTC), he used his ministerial powers to ensure that anticommunist CTC bureaucrats received official recognition and sole bargaining rights. While this was successful in many unions, a takeover of the more militant federations such as the dockers, tobacco workers and sugar workers required the use of police and gangster violence. Amongst those murdered was Jesús Menéndez, shot in the back by Captain Joaquín Casillas on Matanzas railway station while he was touring the country building support for a strike to defend the diferencial. His funeral in Havana in January 1948 was attended by 150,000 people. The struggle to defend sugar workers' pay and conditions continued under another communist, also of African heritage, Ursinio Rojas, but the murder of Jesús Menéndez was a severe blow to the Cuban labour movement (SIMS, 1993).

\section{ARACELIO IGLESIAS}

When both his parents died, Aracelio Iglesias went to live with family friends in Regla, across the bay from the city of Havana, where he started working on the docks at the age of 15 . He came to the attention of some veteran communist port trade unionists who encouraged his involvement in the union and recruited him to the communist party in 1931. During the 1933 general strike the port of Havana was on strike for 19 days. Aracelio Iglesias was elected to the strike committee which went on to organize solidarity action during the tobacco workers strike at the end of that year. In 1934 he was a picket organizer during a dock strike against the ships of the United Fruit Company. After several unsuccessful attempts to arrest him, Iglesias was finally detained and charged with possession of arms and explosives, for which he was imprisoned for three 
years on the Isle of Pines. On his release in 1937, he returned to work in the port where, the following year, he was elected secretary of the Sindicato de Estibadores y Jornaleros de la Bahía de La Habana (Union of Stevedores and Labourers of the Bay of Havana) and in 1939 to the national executive of the Federación Obrera Marítima Nacional (FOMN, National Maritime Workers' Federation) as well as the national executive of the newly-formed CTC. Iglesias was keen to establish legally-determined wages for his members and represented the FOMN on the Comisión de Inteligencia del Puerto (Port Arbitration Committee), which set the rates for loading and unloading ships. But there was no enforcement mechanism for arbitration decisions and he did not hesitate to call strikes and boycotts against any company that was slow to comply. During the Second World War, because of German submarine activity, Havana became the sole authorized port in Cuba, which left the dockers in the rest of the country unemployed. Aracelio Iglesias negotiated a government subsidy to alleviate the hardship in the closed ports, while at the same time opening twenty percent of the Havana roster to dockers from the rest of the country. The war was a period of high inflation in Cuba, but the Havana FOMN was able to put sufficient pressure on the government to decree wage increases which went some way to keeping pace with the cost of living. His unyielding stance on these matters brought him into conflict with the major US shipping lines, who were using the wartime emergency to attack established wages and conditions of work.

The end of the Second World War saw an increased level of industrial disputes, with the employers attempting to increase productivity. In Havana there was constant conflict over mechanization as the dock workers' union opposed the introduction of bulk loading of sugar. The pro-business press directed considerable animosity towards Aracelio Iglesias as the public face of the Havana dockers, with the news magazine Bohemia attacking him in an article entitled "The Most Expensive Port in the World". US Senator Bradley, spokesman for the shipping lines, called him the "Red Czar of the Port" and his membership of the communist party 
was used against him in the increasingly anti-communist atmosphere of the early Cold War.

Despite the 1947 government purge that ended communist control of the trade unions, Aracelio Iglesias had a sufficient base of support to be re-elected FOMN secretary for the port of Havana by a mass meeting in March 1948. The government annulled the election and the Navy and Maritime Police occupied the FOMN office, giving formal control of the union to supporters of the ruling party. This led to strikes and demonstrations, making it evident that the Havana dockers would not easily accept the imposed leadership. On 15th October 1948, a mass meeting voted to refuse to pay their union subscriptions. Two days later, Iglesias was shot in the back by two gunmen acting on behalf of the ruling party as he sat in the makeshift union office. Strikes broke out throughout the country in the days that followed and his funeral became a massive protest in itself. The murder of Aracelio Iglesias was a serious setback for the workers in the port of Havana, but their organization was strong enough to continue resisting productivity measures such that in 1959, at the victory of the Cuban Revolution, bulk loading had still not been introduced (CANTÓN NAVARRO, 1977).

\section{PRODUCTIVITY}

Eusebio Mujal, who become the new general secretary of the CTC in 1949, used his links to the government to secure enough economic gains for the union's membership to maintain his position and to prove that his grouping, referred to as mujalistas, were at least as effective as the communists they had replaced. Thus in 1950, a Havana tram strike led by communists was defeated by police repression, while that same year bank workers were granted their demands on condition that they affiliated to the Auténticocontrolled CTC. Reports from the British Ambassador in 1952 were still full of criticism of the "endless irresponsible demands of the labour movement", which he blamed on Mujal who, he wrote, "imposed his will on the President and secured satisfaction for his every whim, however irresponsible and prejudicial to the long term interests of the country it might be" (CUSHION 2016a, p. 22). 
The removal of the communists from office may have suited the Cold War foreign policy objectives of the US government, but did nothing in itself to improve the productivity of Cuban workers.

If economic conditions had become more difficult generally in the capitalist world during the post war period, Cuba was particularly badly hit by the drop in world sugar prices. The employers' obsession with productivity is described by the 1951 "Report on Cuba", compiled by Francis Truslow for the World Bank affiliated International Bank for Reconstruction and Development, wherein the resistance of workers to mechanisation and other productivity measures are clearly identified as the main problem facing the Cuban economy. The report argues that increased productivity would attract investment, promote diversification and thereby produce jobs. Underneath the pious rhetoric calling for greater co-operation between management and labour lay the concrete proposal to make dismissal of employees simpler, faster and cheaper. The chronically-high level of unemployment deeply affected the consciousness of those in work and job security was always the prime concern of unionised workers (TRUSLOW, 1951, p. 225-230; 338).

Given the strength of the trade unions, there had been little possibility that the Truslow report could be implemented by an elected government, but rather required an authoritarian regime to enforce its proposals which, at least in the short term, could only result in a considerable increase in the already chronic level of unemployment. The army coup on 10th March 1952 that brought in the Batista dictatorship was widely seen in this light at the time. The main business newspaper, Diario de la Marina had been enthusiastically campaigning for Batista with a headline "Batista es el Hombre" (Batista is the Man). When Batista staged his coup, the US and British Embassies noted that businessmen were amongst the new regime's most enthusiastic supporters. Within ten days of the coup, the country's major business associations had visited the presidential palace to offer their support.

The majority of the trade union bureaucracy quickly came to an accommodation with the new regime and Mujal went on to become one of Batista's most loyal collaborators. In return for this 
collaboration, the government turned a blind eye to corrupt practices by Mujal's supporters within the unions and obliged employers to deduct trade union subscriptions from workers' wages by means of a compulsory check-off, which isolated the CTC leadership from rank and file pressure. Batista planned his attack on working conditions carefully. He had reached an accommodation with the CTC but could not move too quickly because, if he undermined Mujal's position, that accommodation would be useless. His approach to restoring profitability was by defeating workers sector by sector, making sure that the field of battle was always chosen by the regime and that any chance of generalised industrial action was avoided. Nevertheless, despite the mujalista bureaucracy's best efforts, the CTC was not monolithic and remained a workers' organisation in which, as well as some honest, independent trade union leaders, the communists still had a level of influence. This was particularly true in the countryside where social legislation was not well enforced and, given that most urban bureaucrats avoided the rural areas, PSP members managed to retain a following.

However, the political situation in Cuba was to be turned upside down by the events of the 26th July 1953 when Fidel Castro led an unsuccessful attack on the Moncada barracks in Santiago, hoping to spark a nationwide insurrection. Having been falsely accused by the authorities of complicity in the Moncada attack, the PSP was included in the generally increased repression which followed the incident, despite condemning Castro's actions as adventurist and arguing that such individual action disorientated the masses while giving the government an excuse for brutal repression. Their newspaper Hoy was closed down, the party was formally banned and the few remaining Communists were purged from the official CTC.

The year of 1955 was a one of intense class struggle in Cuba. Starting with a railway stoppage covering half the island and finishing with a strike by half a million sugar workers, the year also saw militant action by bank workers, telephonists, bus drivers, dockers, cigar rollers, brewers and textile workers. In every case the cause of the dispute was the perception by employers that they needed to drastically increase productivity in order to maintain 
profit levels; a productivity drive that received the full support of the Batista dictatorship.

The mujalista CTC bureaucracy facilitated this productivity drive by placing themselves at the head of any dispute and then almost immediately surrendering. Where workers refused to accept the actions of the trade union bureaucracy, the government used the police and army with considerable brutality to overcome remaining resistance. In return for the support of the mujalistas, the Ministry of Labour used its extensive legal powers of intervention to prevent aggrieved union members voting the incumbent bureaucrats out of office.

When the sugar workers went on strike at the end of 1955 and found themselves faced with a level of repression only previously used to attack militant students, the sugar workers themselves turned to violence: they set up road blocks, burnt cane fields and occupied town halls and city centres; actions that resulted in hundreds arrested or wounded, with Batista's forces killing several strikers.

The strike was finally defeated, but this confrontation destroyed many illusions about the effectiveness of legal, peaceful protest and convinced a significant minority of workers that there was no longer any reformist solution to their problems (ROJAS BLAQUIER, 1998). It is worth noting that this strike was conducted with a high level of inter-racial solidarity and that there were no reported divisions between black and white workers of the sort that had been so detrimental in the 1930s.

The defeat of a well-organised strike by economically-powerful groups of workers with considerable experience in industrial activity made a group of militants in the city of Guantanamo realise that, unless the Batista regime could be militarily defeated, they would no longer be able to defend and advance their conditions and wages. Neither would they be able to regain control of their own trade union while Mujal and his cronies had the support of the state. From the start of the dictatorship in 1952, Guantanamo had been a centre of intense opposition to the Batista dictatorship but the limitations of peaceful methods were becoming obvious when faced with such a level of repression. So for instance when 
Frank País, regional co-ordinator of Fidel Castro's newly formed Movimiento Revolucionario 26 de Julio (July 26th Revolutionary Movement, MR-26-7) visited Guantanamo in September 1955, he recruited a railwayman called Octavio Louit to form the local branch of the revolutionary organisation, an endeavour in which he was helped by another railway worker, Antonio "Ñico" Torres. Torres and Louit proposed a tactic they called Sindicalismo beligerente (trade unionism on a war footing), which combined mass action with sabotage, an approach that led telephone workers to cut phone lines, sugar workers to burn fields and railway workers to derail scab trains during strikes (COMA, 1981).

\section{DIVIDED OPPOSITION}

The strained relationship between the PSP and the rest of the anti-government opposition demonstrates the divisive effect of Cold War anti-communist propaganda. This, despite the complete lack of interest in Cuba displayed by the USSR until some time after the triumph of the revolution in 1959. So the PSP'S uncritical support of the USSR, in particular its support of the crushing of the Hungarian uprising in 1956, played into the hands of its enemies. These attitudes affected the relationship between the PSP and the MR-26-7. The bad start to relations as a result of the PSP'S condemnation of the Moncada attack continued and a distinct anticommunist faction grew in the MR-26-7, particularly in Havana.

The division between these two organisations was much less noticeable in eastern cuba where, particularly amongst militant workers, there was a much more collaborative attitude. This would prove important when Fidel Castro returned to Cuba at the end of 1956 and the MR-26-7 organised an armed uprising in eastern Cuba in order to divert the authorities' attention from Castro's landing in the Granma. The national leadership of the PSP was aware of the impending Granma landing, but they thought that the whole scheme was adventurist and wanted no part of it. However, the local PSP organisation in Santiago had cordial relations with the July 26th Movement and took a different view. As a result, the military actions of the MR-26-7 on 30th November 1956 received 
the support of the Santiago communists led by Ladislao Carvajal, provincial secretary of the PSP, in defiance of a direct order from Havana. This cordial relationship was particularly important in the port. So, on the morning of the 30th November, Juan Taquechel, a leading Afro-Cuban communist militant on the Santiago docks, successfully pulled the port workers out on strike in support of the insurrection organised by the MR-26-7 (TAQUECHEL; POUMIER, 2009, p. 120).

Frank País instructed the MR-26-7 group in Guantanamo to prevent military reinforcements reaching Santiago from the Guantanamo region. This they achieved by a spectacular railway strike during which the whole network at the eastern end of the island was paralysed for five days, all the more impressive because the workers raised no demands other than to make it clear that they were acting in support of their comrades in Santiago. The rest of the town managed to maintain a general strike for a couple of days, while the workers in the processing plant of the Ermita sugar plantation, where the MR-26-7 had two active cells, successfully attacked the police barracks on the plantation. As a result of the success of the strike in Guantánamo, Ñico Torres, now a wanted man, was made chair of a commission charged with extending sindicalismo beligerente nationwide and he spent the next year criss-crossing the island with this objective.

\section{DEATH SQUADS}

The government response to the start of rebel guerrilla activities in the Sierra Maestra was violent repression. It was quite common for a jeep full of plain-clothes police or off-duty soldiers to arrive outside the house of an opponent of the regime and shoot him in front of his family and neighbours. There were several mass demonstrations against this state-inspired terror in the early part of 1957, with perhaps the most successful being the town-wide general strike to protest against police and army brutality in Manzanillo on 28th January 1957, supported by a partial stoppage in the towns of Santiago and Contramaestre. Manzanillo had always been a communist party stronghold; it was, after all, the home town 
of the party leader Blas Roca and was now the nearest town of any size to the rebels in the Sierra Maestra. There was a personal relationship between many local militants of the PSP and the MR-26-7 in Manzanillo. Local communists, particularly members of the PSP youth wing, the Juventud Socialista, often helped in the support networks for the rebel army, although how much of this was known to the leadership in Havana is uncertain.

In the summer of 1957, Frank País, now the MR-26-7 National Co-ordinator of Action, was based in Santiago from where he was working both to promote the movement's clandestine operations and to organise support for the guerrillas in the nearby Sierra Maestra mountains. His murder at the end of July 1957 by a local police chief produced a general strike in Oriente province, which was probably the biggest public demonstration of opposition during the entire Batista dictatorship. Following his funeral, the whole city of Santiago de Cuba was shut down by a general strike which lasted 5 days. The strike spread to cover the entire eastern half of the island, but failed to reach Havana. Efforts to launch a strike in Havana on August 5th were unsuccessful outside of a few traditionally militant sectors such as public transport, due in part to some swift action by the mujalista bureaucracy. This strike gave the question of possible collaboration between the MR-26-7 and the PSP an increasing significance and there was some basis for the discussions which started in February 1958 with the arrival in the Sierra Maestra of a PSP delegate, Carlos Rafael Rodríguez (KAROL, 1970, p. 150).

\section{APRIL 9TH SETBACK}

Discussions with the PSP had not advanced greatly by the time the MR-26-7 called a general strike on 9th April 1958. This strike, which received almost no working class support, was a complete disaster and cost the lives of many of the movement's best underground activists, as Batista's chief of police issued the instruction: "No wounded, no prisoners". The process of picking up the pieces began with a meeting of the MR-26-7 leadership on May 3rd at Los Altos de Mompié in the Sierra Maestra. From the point of view of 
working class involvement in the insurrection, two important decisions were taken, one of which was to give future priority to the guerrilla struggle, the other was to reorganise the M-26-7 workers' section, now called the Frente Obrera Nacional (FON - National Workers' Front) under the leadership of Nico Torres. A new theme of the reorganised FON was a call to unity, which reflected the realignment towards the communists that was emerging from the discussions between Fidel Castro and the PSP delegate, Carlos Rafael Rodríguez.

The terror unleashed by the regime following the strike of 9 April 1958, widely reported in the PSP press, convinced the party's leadership that there was no possibility of a legal solution to the crisis and that there was a need for armed protection before workers would take further action. It had also become clear that the MR-26-7 was now, irrespective of the defeated strike, the centre of opposition to Batista and other political organisations would have to re-orientate toward them. The PSP national leadership therefore decided, towards the end of April, to publicly support the guerrillas.

Going on strike in Batista's Cuba could be a life or death decision and workers had to feel some confidence in their chances of survival and in the possibilities of successfully gaining a result that would be in their political and economic interests. In the summer of 1958, however, the guerrillas still had to beat the encircling forces of Batista's army, which outnumbered them enormously. The army and police, while they had demonstrated ruthless efficiency when shooting down poorly armed students or unarmed striking workers, were not nearly so determined when faced with well trained and politically motivated guerrillas, who rapidly gained the military upper hand in the second half of 1958. There was a parallel growth in financial support coming from workers through late summer and autumn, as well as the increase in membership of the FON, which was estimated at 15,000 by the end of the year (ALEXANDER, 2002, p. 159).

Discussions aimed at uniting all oppositional workers' organisations started on 21st June at a meeting between the MR-26-7 and the PSP although final agreement was not reached until 10th 
November when the Frente Obrero Nacional Unido (FONU, United National Workers' Front) was launched (PCC 1985, p. 352-360). Two "Workers' Congresses in Liberated Territory" were called in the name of FONU at the end of 1958, one in the Sierra Cristal mountains in the area controlled by the rebels' Second Eastern Front, led by Raúl Castro, and the other in northern Las Villas province in the area controlled by rebel forces under the command of Camilo Cienfuegos, who appointed a communist bus driver, Gerardo Nogueras, to head his workers' commission and asked the veteran PSP sugar worker, Ursinio Rojas, to address the congress. In a gesture of repudiation of the racism that had so undermined the 1933 revolution leading to the 1935 counter-revolution, the congress in the Sierra Cristal deliberately appointed a descendent of Haitian immigrants as president of the session (CARDONA BORY, [1995]).

These congresses gave the rebel movement considerably increased legitimacy in working class circles, also showing that the PSP and MR-26-7 forces amongst organised labour were publicly united and capable of creating an alternative organisational structure. They were important events in themselves, the difficulties involved in assembling several hundred delegates in conditions of dictatorship and civil war showing an impressive level of organisation. But they are crucial to understanding how the revolutionary general strike that overthrew Batista was organised and proved so powerful that it pulled the rest of the population in behind it. This next strike was planned to start in January 1959 to coincide with the start of the sugar harvest, thereby maximising its economic effect. In the event, these preparations had to be brought forward to take advantage of the opportunity afforded by the flight of Batista on New Year's Day 1959.

However, there was a real possibility that an army coup, particularly if it was led by an honourable patriotic officer without previous close association with Batista, could have split some of the middle class support away from the MR-26-7 and prolonged the civil war. As the rebels moved in to seize Santiago on New Year's Morning 1959, Fidel Castro spoke over the radio to condemn the coup attempts and to call for a revolutionary general 
strike. This call was directed at all workers in territory not yet liberated and told them to organise in all workplaces to totally paralyse the country. From the moment the call went out, the strike was complete. Fidel Castro himself affirmed that the general strike was decisive in delivering the fortresses of the capital of the republic, in defeating the final manoeuvres of the enemies of the people and in giving all power to the revolution (CUSHION 2016b, p. 198).

The strike provided such powerful evidence of the overwhelming popularity of the rebel victory that the army chiefs quickly abandoned their plans for a military coup. Furthermore, the strike gave an authority to the MR-26-7 militias that were keeping order in the streets of Havana for that first week in January, thereby preventing the scenes of violent disorder and lynch mob rule that had followed the downfall of Machado. Another important aspect of the general strike was the way in which it placed the MR-26-7 in complete control. The popular reaction to Fidel Castro's triumphant passage from Santiago to Havana demonstrated quite clearly who the new power in the land was.

\section{CONCLUSION: THE RELATIONSHIP BETWEEN THE PSP AND THE MR-26-7}

The growth of the MR-26-7 had inevitably brought its membership into contact with PSP militants at workplace level. The dynamics of workplace organisation forced these two groups of militants to interact and, while there was continued political debate and disagreement, a process of convergence started to occur considerably before the developing relationship at leadership level. A good example of this is the history of active solidarity between the largely Afro-Cuban Santiago port workers led by the communist Juan Taquechel and the mainly white workers in the city's Bacardí distillery led by MR-26-7 militant Ramón Álvarez, which was a crucial factor in Juan Taquechel's decision to lead the dockers out on strike in support of the MR-26-7 uprising on 30th November 1956.

The differences between the two organisations were largely tactical, with the PSP promoting unarmed mass struggle, while the 
MR-26-7 saw the need for armed action to defeat the forces of state repression. Both organisations placed the general strike at the centre of their approach, but they had a very different conception of the tactic. To the PSP it represented a traditional stoppage of work by the overwhelming majority of workers, who would thereby achieve their objective by sheer weight of numbers and by paralysing the economy. To the MR-26-7, the general strike was more akin to a mass armed popular insurrection. As opposition to the Batista regime grew, the difference between these tactical approaches was tested in practice. The PSP leadership learnt the need for armed support, while the M-26-7 leadership realised that popular support could not just be summoned, but had to be built by relating their propaganda to workers' economic and social interests.

A view of the Cuban Revolution which sees the rebel victory as entirely the work of the guerrilla army will necessarily see little contribution from the communists. If the role of organised labour is taken into account, the communist contribution becomes considerably more significant, as this is the area in which they operated most effectively. The communist party was also the major organisation of Afro-Cuban workers, who represented at least a third of the membership. Thus, the systematic agitation and propaganda by communist militants was a key factor in helping maintain independent working-class organisation, while their organisational experience and pre-existing militant networks complemented the work of the MR-26-7 workers' section. The party's constant anti-racist propaganda, which they linked to anti-imperialism by repeatedly drawing attention to the disgraceful oppression of Afro-Americans in the US South, helped to maintain that inter-racial solidarity that is so important to successful industrial action. The PSP had some very impressive Afro-Cuban clandestine working class organisers, most of whom are forgotten because of the necessary anonymity forced on militants during a brutal dictatorship. Two whose trajectory is known can stand for many others. The first is sugar worker Pablo Sandoval, whose name is on many documents in the Camaguey provincial archive, first as secretary of the provincial federation of the CTC until 1948, then signing leaflets appealing for resistance 
in the name of various communist front organisations. He went underground and was particularly in evidence around the sugar strike in Central Estrella in 1955 and then reappears in 1959 after the rebel victory calling for unity on the May Day march. The second, Vicente Pérez, was a communist tobacco worker from Caibarien who was at the founding conference of the CTC and was working full time as a party industrial organiser by 1957, actively supporting the dock workers fight against mechanisation. He was sent to Pinar del Río province to help organise tobacco workers in 1958.

In circumstances where a regime is prepared to use high levels of brutality to suppress workers' attempts to defend their wages and conditions, then conventional methods of mass action, such as the strike, the demonstration or the boycott, are insufficient. Equally, armed guerrilla action without mass support normally leads to isolation and defeat. The victory of the revolutionary forces in Cuba in 1959 was due to a successful combination of these tactics, while the important contribution of militant Afro-Cuban workers to the "red-thread" that links the Russian Revolution to the Cuban Revolution has been unfairly neglected.

\section{REFERENCES}

ALEXANDER, R. A History of Organized Labor in Cuba. Westport, Conn: Praeger, 2002.

ADI, H. Pan-Africanism and Communism: The Communist International, Africa and the Diaspora, 1919-1939. Trenton, New Jersey: Africa World Press, 2013.

CANTÓN NAVARRO, J. Aracelio Iglesias. La Habana: Editorial Arte y Literatura, 1977.

Cuba bajo el signo de la Segunda Guerra Mundial, 1940-

1944. La Habana: Editora Historia, 2013.

CARDONA BORY, P. Memorias del Congreso Obrero en Armas, Segundo Frente "Frank País". Cuba: Pilar Casada González, [1995].

CARR, B. Mill Occupations and Soviets: The Mobilisation of Sugar Workers in Cuba 1917-1933. Journal of Latin American Studies, Cambridge, v. 28, n. 1, p. $129-158,1996$. 
CASTRO FERNÁNDEZ, S. La masacre de los independientes de color en 1912. La Habana: Editorial de Ciencias Sociales, 2008.

COMA, I. A. El movimiento 26 de Julio en Guantánamo. Santiago de Cuba: University of Oriente, 1981.

CHASTEEN, J. C. Born in Blood and Fire. London: W.W. Norton, 2006.

CUSHION, S. A Hidden History of the Cuban Revolution: How the Working Class Shaped the Guerrillas' Victory. New York: Monthly Review Press, 2016a.

Killing Communists in Havana. London: Socialist History Society Occasional Publication, 2016b.

FUENTE, A. de la. Two Dangers, One Solution: Immigration, Race, and Labor in Cuba, 1900-1930. International Labor and Working-Class History, Cambridge, n. 51, p. 30 - 49, 1997.

A Nation for All: Race, Inequality and Politics in Twentieth Century Cuba. Chapel Hill, N.C. ; London: University of North Carolina Press, 2001.

FERRER, A. Insurgent Cuba. Chapel Hill: University of North Carolina Press, 1999.

FONER, P. S. The Spanish-Cuba-American War and the Birth of American Imperialism. New York: Monthly Review, 1972.

HATZKY, C. Julio Antonio Mella. Santiago de Cuba: Editorial Oriente, 2008.

HART, R. Labour Rebellions of the 1930s in the British Caribbean Region Colonies. London: SHS/CLS, 2002.

IBARRA CUESTA, J. Prologue to Revolution: Cuba, 1898-1958. London: L. Rienner Publishers, 1998.

KAPCIA, A. The Siege of the Hotel Nacional, Cuba, 1933: A Reassessment. Journal of Latin American Studies, Cambridge, v. 34, n. 2, p. $283-309$, 2002.

KAROL, K. S. Guerrillas in Power: The Course of the Cuban Revolution. New York: Hill \& Wang, 1970.

KERSFFELD, D. De Cara al Sol. La Habana: Editorial Historia, 2009.

PCC - Partido Comunista de Cuba. Historia del movimiento obrero cubano. La Habana: Editora Política, 1985. [Instituto de Historia del Movimiento Comunista y de la Revolución Socialista de Cuba].

PÉREZ, L. Cuba and the United States: Ties of Singular Intimacy. Athens, Georgia: University of Georgia Press, 1990. 
PINO SANTOS, O. Historia de Cuba. La Habana: Editorial Nacional, 1964. POLLITT, B. H. The Rise and Fall of the Cuban Sugar Economy. Journal of Latin American Studies, Cambridge, v. 36, n. 2, p. 319 - 348, 2004.

RIVERO, S. La sombra de Marcus Garvey sobre el Oriente Cubano. Santiago de Cuba: Ediciones Santiago, 2005.

ROJAS BLAQUIER, A. 1955 - Crónica de una marcha ascendente. La Habana: Instituto de Historia de Cuba, 1998.

El primer partido comunista de Cuba 1925 - 1935. Tomo 1. Santiago de Cuba: Editorial Oriente, 2005.

El primer partido comunista de Cuba 1935 - 1952. Tomo 2. Santiago de Cuba: Editorial Oriente, 2006.

SIMS, H. D. The Cuban Sugar Workers' Progress Under the Leadership of a Black Communist, Jesús Menéndez Larrondo (1941- 1948). MACLAS Latin American Essays, Ashland, v. VI, p. 9 - 21, 1993.

TAQUECHEL, R.; POUMIER, M. Juan Taquechel López y el movimiento obrero en Santiago de Cuba. Santiago de Cuba: Colleción El Cobre, 2009.

TRUSLOW, F. A. Report on Cuba. Washington, D.C.: International Bank for Reconstruction and Development, 1951.

WHITNEY, R. State and Revolution in Cuba. Chapel Hill: University of North Carolina Press, 2001.

ZANETTI, O.; GARCÍA, A. Caminos para azúcar. La Habana: Editorial de Ciencias Sociales, 1987.

ZUMOFF, J. The Communist International and US Communism 19191929. Chicago: Haymarket, 2015. 